\title{
Service Innovation by Industrial Cluster Formation and Export Promotion
}

\author{
Noleen Pisa \\ University of Johannesburg, South Africa \\ noleenp@uj.ac.za \\ Sonja Grater \\ North-West University, South Africa \\ sonja.grater@nwu.ac.za \\ Riaan Rossouw \\ North-West University, South Africa \\ riaan.rossouw7@gmail.com
}

Service innovation drives economic growth and structural change by stimulating the development of new sectors and productivity improvements in existing sectors. Resource based sectors are the main contributors to South Africa's North West province's economic output This paper illustrates how such a region can use industrial cluster formation and focused export promotion as a strategy to enhance service innovation. Four service clusters were identified within the above mentioned province through structural path analysis and power of pull methods. An export market selection model is applied to the identified service industrial clusters to reveal realistic export opportunities associated with each cluster. Finally, trade multipliers are used to show the spill-over benefits given an increase in the clusters' exports. Policymakers can use these results to inform actions that may assist in the development of these services clusters to strengthen the province's competitive advantage and diversify its output.

Key Words: Service innovation, industrial clusters, export promotion, trade multipliers, TRADE-DSM ${ }^{\circledast}$

JEL Classification: R110, F140

https://doi.org/10.26493/1854-6935.15.321-340

\section{Introduction}

Growth and competitiveness are key goals for most economies and are driven by mainly the manufacturing and service sectors, technological innovation and service innovation. The services sector is progressively vital for growth in the global economy (Nordås and Kim 2013). The success and competitiveness of manufacturing is now more dependent on innovative services such as design, marketing, logistics and product-related 
after sales services. Service firms are therefore providing complimentary services for manufactured goods and services related to distribution channels (Chesbrough 2011). According to European Commission (2012) service innovation is characterised by 'significantly improved or novel service concepts (either in the manufacturing or services sector), innovation services processes, establishment or improvements in service infrastructure, customer processing, business models, commercialisation (sales, marketing and delivery), service productivity and hybrid forms of innovation serving several user groups in different ways simultaneously'. Service innovation transforms distribution channels, business processes, and models to transform the entire value chain and significantly enhance the customer experience (Chesbrough 2011).

This study focuses on the North West province (NWP) of South Africa. The economy of this province is currently driven mainly by the mining sector, which accounts for almost $36 \%$ of the economic output of the province (see http://www.ihsglobalinsight.co.za). $84 \%$ of South Africa's platinum output, $46 \%$ of the granite output and $25 \%$ of the gold output originated from the NWP (Credit Guarantee 2010). The NWP also produces significant quantities of cement, coal, copper, diamonds, dimension stone, fluorspar limestone, manganese, nickel, phosphate, slate, uranium and vanadium (Credit Guarantee 2010). Macroeconomic instability and the decline of manufacturing sector are consequences of dependence on resource-based sectors (Eitzen 2012). The recent decline in manufacturing as a result of over-reliance on resource-based sectors undermines economic growth and development (Kingstone 2012).

In this study, the promotion of service industrial clusters is proposed as a strategy to enhance service innovation and export success. Secondly, this paper aims to identify realistic export opportunities (REOS) for the service industrial clusters according to the TRADE (Trade and Development) - Decision Support Model (TRADE-DSM ${ }^{\circledast}$ ) to enhance these clusters' probability of export success and further enhance the province's competitiveness. Thirdly, trade multipliers are calculated to elaborate on the inter-linkages that exist between the services cluster sectors.

The following section will discuss the background on industrial cluster formation and the role it plays in driving growth, with a special focus on the services sector. The third section then explains the research methods. While the results of the identified service clusters, the REOS of the TRADE-DSM ${ }^{\circ}$ for services and the trade multipliers are presented in the fourth section. The conclusions and recommendations are presented in the fifth section. 


\section{Role of Service Industrial Clusters and Exports in Growth}

SERVICE INDUSTRIAL CLUSTERS AS A SOURCE

OF GROWTH AND INNOVATION

The interdependence between firms in an industrial cluster can incubate innovation. Porter (1989) highlighted that long-term sustainable advantages for a firm or a region can be derived from innovation. Industrial cluster enhance innovation and productivity growth through improved technical and technological capabilities (Porter 1998). Systematic linear processes, adaptation and self-organisation of behaviour by entrepreneurs result in the formation of systems of innovation in clusters (Feldman, Francis, and Bercovits 2005).

Competition among firms is no longer driven by price only, but also by innovation, technology and the development of innovative products. Technology, according to Smillie $(1991,9)$ 'is the science and art of getting things done through the application of skills and knowledge. Technology improves the types of tools available for executing tasks, the knowledge skills and routines that are vested in people (Lall 1992). The use of machinery demonstrates the physical use of technology (Lall 1992). Knowledge creation in a cluster is facilitated by the presence of multiple suppliers and institutions (Porter 200o). Cluster formation enhances the technical and technological capabilities of small firms (Porter 2000).

Service innovation strengthens an economy's industrial base and stimulates innovation in other industries thereby creating an enabling environment for the formation of new economic and industrial sectors (Chesbrough 2011). Cross-sector fertilisation is possible with the existence of service industrial clusters as they enable structural change and innovation (Bishop and Gripaios 2007). Cooperation among cluster firms from different sectors or industries results in effective value chains that are characterised by innovation, knowledge transfer and new product development (Tallman et al. 2004; Hansen and Birkinshaw 2007). Service innovation offers opportunities to advance the competitive position of regions with an industrial base that is not positioned at a technological frontier such as the NWP (European Commission 2012).

\section{INTERNATIONALISATION THROUGH EXPORTING}

In an environment of increased global integration and competition small and medium-sized enterprises (SMEs) need to innovate, and to internationalise to remain competitive (Van Laere and Heene 2003). Internationalisation and industrial cluster formation were identified as ways to 
capitalise on the challenges and opportunities presented by globalisation, especially for firms in developing countries (Awuah 2009).

New markets can be served from existing manufacturing bases without having to establish production plants in other markets through exporting (Czinkota and Ronkainen 2007; Doole and Lowe 2004). The competitiveness of firms that rely on the domestic market can be threatened by shifts in consumer preferences, new competitors or economic downturn. These variations lead to decreased sales volumes, profits and growth prospects (Leonidou et al. 2007). Internationalisation reduces over dependence on domestic markets and business risks associated with dependence on one market. This is achieved by taking advantage of the differences in market share growth, the different stages and the intensities in different countries' business and product cycles (Albaum, Strandscov, and Duerr 2004; Trimeche 2002; Czinkota 2002). This study uses the results of a scientific export market selection model, the TRADE-DSM${ }^{\circ}$ for services to devise appropriate export strategies for each services clusters for the NWP combination.

\section{Methods}

The current paper follows and applies the same method used, to identify service industrial clusters in the NWP, from a previous study. Details of these methodologies including SPA, POP and the DSM methods have been described and published in detail elsewhere (Pisa 2014; Cuyvers and Viviers 2012). Below we summarise the main methods mentioned above and how they were applied to add rigour and coherence to the results presented in the current manuscript.

\section{STRUCTURAL PATH ANALYSIS}

Structural path analysis was conducted on a provincial social accounting matrix (SAM) for the NWP, using Sim SIP Sam, a Microsoft Excel macro which utilises the MATLAB platform (Parra and Wodon 2009). SPA enables the observation of the flow of income by decomposing the transactions (inter-industry linkages) between the various sectors of the economy. To trace the inter-industry linkages between sectors, SPA simulates and traces the effects of an injection into each sector in the economy. Once this injection is made into a specific sector, the increases in that sectors consumption of inputs, the subsequent increases output and household incomes and spending can be traced. Inter-industry linkages within NWP were explored using the fixed origin analysis which implies that 
only the direct multiplier effects from a fixed origin (sector) are traced in the economy. The indirect multiplier effects that feed back into the initial sector in which the injection was made are not analysed.

One of the main shortcomings of the SPA method is that it does to identify or rank the clusters in order of their importance in effecting multiplier effects in the rest of the economy. The power of pull (POP) method was also used to prioritise the number of clusters.

POWER-OF-PULL

To prioritise the number of clusters for the NWP the power of pull (POP) method was applied to the SPA results (Pisa 2014). Dietzenbacher (1992) proposed the method to calculate the power of pull. This method analyses eigenvectors of the major eigenvalues of an inter-industry transaction matrix. The eigenvector method captures the network perspective and the infinite regressive nature of inter-industry influences. Also, the eigenvector method assigns weights to inter-industry linkages in a systematic way to enable the determination of the importance of industry sectors. By applying the SPA and subsequently the POP method to a SAM for the $\mathrm{NWP}$, industry sectors' power of pull can be assessed and ranked to determine the most important service industrial clusters.

To further prioritise the identified clusters in terms of potential output and exports the results of the power of pull (POP) method can then further be combined with the results of the TRADE-DSM ${ }^{\circledR}$ for services. This model helps to identify the most REOS for a specific sector in a given country and can rank the export opportunities so that the relevant government decision makers can further focus their limited resources on sectors that have the greatest export potential.

\section{THE TRADE-DSM ${ }^{\oplus}$ FOR SERVICES TO IDENTIFY REOS}

The TRADE-DSM ${ }^{\circledast}$ for services uses available data for services in South Africa and aims to determine the REOs for South African services. The model follows a sequential filtering process with four filters that identify services and markets with the most REOs for export success (Grater et al. 2014). Cut-off values are determined (Grater and Viviers 2012) in Filters 1 to 3, and those countries and services that do not comply with the minimum requirements for that filter are eliminated from further analysis. The first filter evaluates political and commercial risk, as well as macroeconomic size and growth performance of each country in the world. Filter 2 incorporates trade data for services and evaluates 
the size and growth of import demand for services in each country, in the short term and long term. This is done based on sub-sector data for services that are grouped according to the Extended Balance of Payments (Е вор s) classification system (United Nations 2002). Trade data for this paper was obtained from TradeMap for the period 2007 to 2011 (see http://www.trademap.org).

Filter 3 comprises filter 3.1 and 3.2. Filter 3.1 uses the import penetration method which is a measure of market openness (Economic and Social Commission for Asia and the Pacific 2009). This method measures the ratio between the imports of a specific service in a specific country, and the total demand for that service in the domestic market (which is calculated using domestic services produced plus all imports of that service minus all exports of that particular service). This calculation is used as a proxy for market concentration, or openness of the market for imports. The results from filter 2 are then also further analysed in filter 3.2, where the model calculates market accessibility for each service in each country. This is calculated using a method developed by Hoekman (1996) to quantify each country's General Agreement on Trade in Services (GATs) commitments. This method quantifies commitments into an index for market access for each country. In filter, 4 services and markets are not eliminated but are categorised into a realistic export opportunity matrix. A more detailed explanation of the methodology is available in Grater and Viviers (2012).

\section{TRADE MULTIPLIERS}

As described in Tarp, Roland-Holst, and Rand (2002) and Parra and Wodon (2009), the starting point for calculating trade multipliers is a standard SA M where all accounts except the rest of the world are considered to be endogenous. From there, the corresponding matrix of expenditure shares (or $A$ matrix) can be calculated with each cell in the resulting matrix representing the expenditure share of each sector in the SAM. Let $M$ be the multiplier matrix (see equation 1), that is,

$$
M=\left[\begin{array}{rrr}
A_{a a} & A_{a f} & A_{a d} \\
I-A_{f a} & A_{f f} & A_{f d} \\
A_{d a} & A_{d f} & A_{d d}
\end{array}\right],
$$

where $I$ is the identity matrix. Then it is possible to compute the import (equation 2) and export (equation 3 ) dependence multipliers as follows: 


$$
\begin{aligned}
M_{M} & =\left[A_{r} a ; A_{r} f ; A_{r} d\right] M \\
M_{E} & =M\left[A_{a} r ; A_{f} r ; A_{d} r\right]^{\prime}
\end{aligned}
$$

The columns of the import dependence multiplier matrix $M_{M}$ capture the particular relationships between variables resulting from a uniform leakage from a local institution or province to the rest of the world and does not affect the witnessed design of expenditure on imports. It shows the resulting demand for imports prompted by a uniform increase in total exports. The weighted averages of the rows of matrix $M$ are shown as columns in the export dependence multiplier matrix $M_{E}$. The expenditure shares of the rest of the world are used as weights in the calculation and measure the change in the total income of each domestic account resulting from uniform flows of funds from the rest of the world, short of changing the composition. A complete view of the dependence multipliers regarding transfer, open-loop, and closed-loop effects, can be captured if the additive breakdown of the multiplier matrix $M$ is used in equations (2) and (3) (Parra and Wodon 2009).

The next section discusses the results of the above analyses applied to the NWP data from the provincial SAM.

\section{Results}

\section{IDENTIFYING SERVICE INDUSTRIAL CLUSTERS}

The SPA and POP methods identified and ranked the inter-industry linkages of all the sectors in the NWP economy. Four service clusters were identified as the highest ranking (in terms of inter-industry linkages) and most influential in the NWP. The following section describes and depicts the identified clusters. The lines in the diagrams represent the intensity of inter-industry linkages between two sectors, with thicker lines representing high intensity and vice versa. The absence of a line between two sectors in a cluster implies that there are no direct transactions between the two sectors.

\section{COMMUNICATION CLUSTER}

The first service cluster to be identified was the communication cluster. Figure 1 illustrates the sectoral composition of the cluster. Six sectors make up the communication cluster namely; building and other construction; communication; electricity; real estate; trade and transport. The highest intensity of inter-industry linkages in the cluster lie 


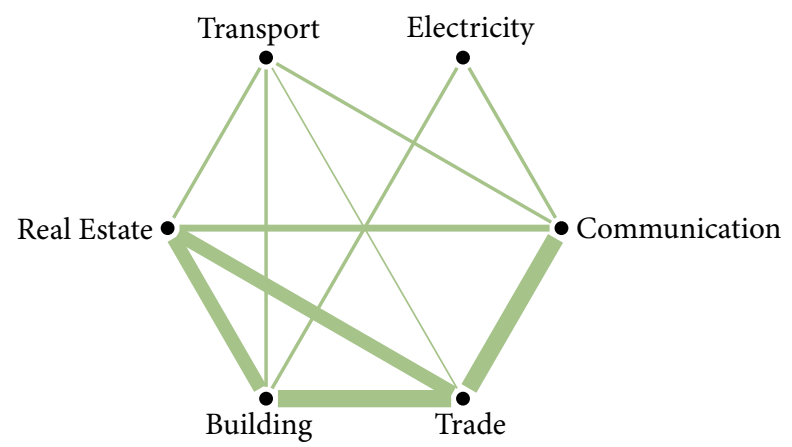

FIGURE 1 Communication Cluster: Sectoral Composition in the NWP

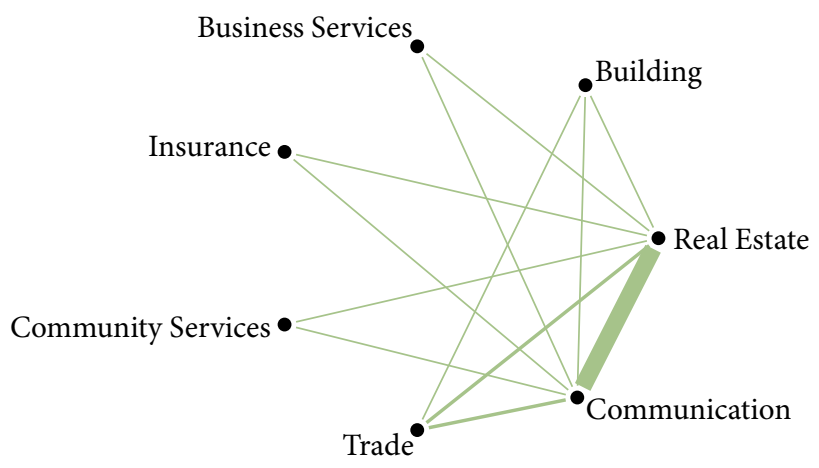

FIGURE 2 Real Estate Cluster: Sectoral Composition in the NWP

between the communication; building and other construction; real estate and trade sectors. The communication sector through information communication technologies (ICT) is vital for service innovation as it facilitates the flow of resources and enables firms to execute inter-firm transactions effectively (Lusch and Nambisan 2015; Barret et al. 2015). ICT and communication between partners in clusters is pivotal to cocreating new products, services and inter-firm processes (Barret et al. 2015; Lusch and Nambisan 2015).

\section{REAL ESTATE}

The real estate cluster comprises seven sectors as depicted in figure 2. The strongest inter-industry linkages are between the communication and real estate sectors. The real estate cluster in this study demonstrates characteristics of a logistics cluster also known as a logistics real estate cluster. 


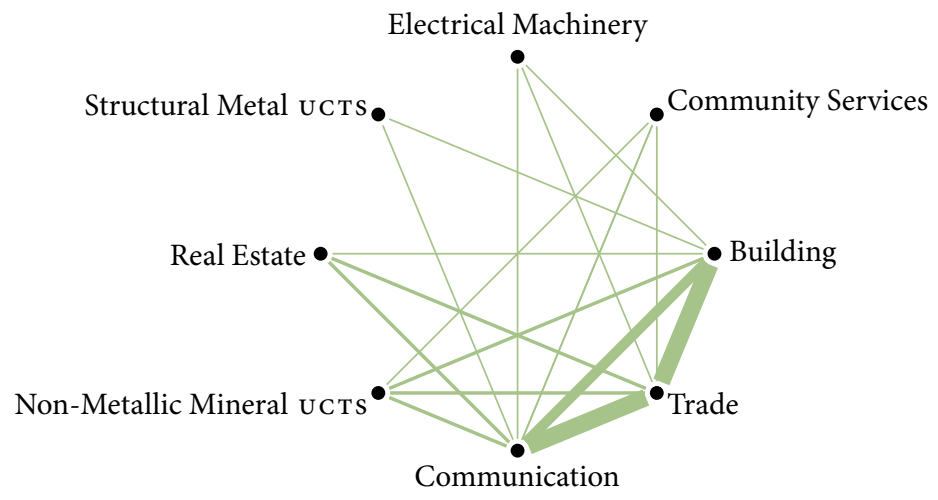

FIgURE 3 Building and Other Construction Products Cluster: Sectoral Composition in the NWP

A logistics cluster is defined as a geographic concentration of distribution centres (Sheffi 2012). The main aim of agglomeration of distribution centres is to serve local customers concentrated in a specific geographic area (Prologis 2015). Alternatively, this agglomeration of distribution centres near transit infrastructure may be aimed at serving and or facilitating global trade (Prologis 2015). Resultantly, as demonstrated by the findings in this study the communication and trade sectors would receive the most benefit from an injection into the real estate sector, and not building and other construction, business services, or insurance.

\section{BUILDING AND OTHER CONSTRUCTION}

The building and other construction cluster was identified as the third possible services cluster in the NWP. Eight sectors make up this cluster (see figure 3). The communication and trade sectors exhibited the strongest inter-industry linkages with the building and other construction sector.

\section{TRADE CLUSTER}

The trade cluster comprises the highest number of sectors, fourteen sectors relative to the other identified clusters. This implies that this cluster can exert influence on the rest of the economy when the number of sectors directly influenced by an injection into the trade sector are considered. The trade cluster can be the catalyst of structural change and industrial modernisation in the NWP. The trade cluster has great potential to have high transformative power through service innovation as it com- 


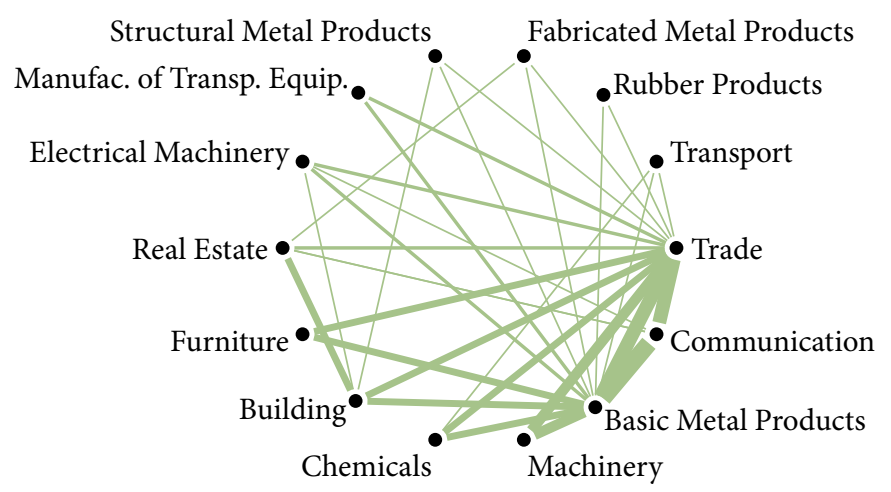

FIGURE 4 Trade Cluster: Sectoral Composition in the NWP

TA B LE 1 Identified Industrial Clusters: Corresponding HS chapters, E B OPS and CPC

\begin{tabular}{lll}
\hline Cluster & EBOPS codes & CPC codes \\
\hline Communication & $245-247$ & N/A \\
Real estate & N/A & $821-822$ \\
Building and other construction & $249-251$ & N/A \\
Trade & N/A & $741-742,748-749$ \\
\hline
\end{tabular}

prises different sectors and this can facilitate cross-sectoral fertilisation and new business models.

DETERMINING REOS OF THE SERVICE INDUSTRIAL CLUSTERS

Table 1 lists the four identified service industrial clusters for the NWP. The identified services clusters are ranked according to the POP scores. These represent a sector's ability to influence other sectors through interindustry linkages or transactions in the network. The SAM uses aggregated sector data, classified under Standard Industrial Classification (SIC). The TRADE-DSM ${ }^{\otimes}$ for services uses data for services classified according to the United Nation's в в ор s system and Central Product Classifications (CPC) codes. To enable comparison of the data, conversion into the same classification was required. Table 1 shows the corresponding ЕВОРS and CPC classifications associated with the four identified clusters.

Table 2 shows the services clusters with REOS for the NWP. Two of the four clusters had REOS namely; communication and building and other construction clusters. REOS in the communication cluster exist in 
TABLE 2 Identified Industrial Cluster Services with REOS

\begin{tabular}{lllrr}
\hline$(1)$ & $(2)$ & $(3)$ & $(4)$ & $(5)$ \\
\hline Communication & 246 & 3.1 Postal and courier services & 5 & $2,459,103.00$ \\
& 247 & 3.2 Telecommunication services & 33 & $49,978,671.00$ \\
\hline Real estate & N/A & N/A & N/A & N/A \\
\hline $\begin{array}{l}\text { Building and other } \\
\text { construction }\end{array}$ & 250 & 4.1 Construction abroad & 20 & $33,147,907.00$ \\
& 251 & $\begin{array}{l}4.2 \text { Construction in the } \\
\text { compiling economy }\end{array}$ & 24 & $32,843,182.00$ \\
\hline Trade & N/A & N/A & N/A & N/A \\
\hline
\end{tabular}

NOTES Column headings are as follows: (1) cluster, (2) в в о Ps code, (3) services sector, (4) number of opportunities, (5) total imports 2011 (US\$ thousands).

E B OPS codes 246 and 247 (postal and courier services and telecommunication services. The building and other construction cluster's REOS were EBOPS 250 and 251 (construction in the compiling economy and construction abroad). These REOS have export opportunities to 20 and 24 countries, respectively. All other service clusters did not have REOS.

Table 3 presents the communication services cluster's top REOS i.e. the potential export markets for the identified South African service clusters. The top four opportunities for the communications services cluster ranked according to the total import value in 2007 are Canada, Hong Kong, United Kingdom and United States of America.

The results can also be classified according to the market size and access determined in filters 2 and 3. Opportunities in the communication services cluster for South Africa in Hong Kong are classified in a large market with short and long term growth, indicating high market openness and high market access. Canada and the United Kingdom are classified in a large market with low market openness but high market access.

As mentioned above real estate and trade clusters were found to have no REOS. For the building and other construction cluster, Germany, Japan, and Russia had the highest imports of construction services in 2011, regarding import values. However, although Germany, Japan, and Russia are large markets for construction services, it has low market openness and market access. If the NWP's communication cluster explores these export markets, strategic planning, and funding.

The NWP can, therefore, use these results to shape their export promotion strategies. The specific clusters can be targeted and specific strategies formulated for each of the potential markets. For example, the communi- 
TABLE 3 Top Potential Export Markets per Service Cluster

\begin{tabular}{llrrr}
\hline$(1)$ & $(2)$ & $(3)$ & $(4)$ & $(5)$ \\
\hline Communication & Hong Kong & 246 & 3.1 & $1,285,843.00$ \\
& Canada & 246 & 3.1 & $796,316.00$ \\
& United States of America & 247 & 3.2 & $7,792,000.00$ \\
& United Kingdom & 247 & 3.2 & $6,341,515.00$ \\
\hline Real estate & N/A & N/A & N/A & N/A \\
\hline Building and other & Japan & 250 & 4.1 & $7,702,323.00$ \\
construction & Germany & 250 & 4.1 & $6,612,868.00$ \\
& Japan & 251 & 4.2 & $7,702,323.00$ \\
& Russian Federation & 251 & 4.2 & $5,315,750.00$ \\
\hline Trade & N/A & N/A & N/A & N/A \\
\hline
\end{tabular}

Notes Column headings are as follows: (1) cluster, (2) country, (3) EB ops code, (4) services sector, (5) total imports 2011 (US\$ thousands).

cation sector shows great potential in Hong Kong, which is a market that is large and growing in the long term. These services-country combinations also have high penetrability and high market access, and therefore, should be accompanied by very offensive export promotion strategies.

Another example is an opportunity for building and construction in Japan, which falls in large markets, have high market access regarding GATS commitments (filter 3.2), but have low market penetrability (filter 3.1). Therefore, the market may be supplied mostly by local firms in the building and construction industry, and the NWP will need to specifically investigate this market together with local firms to determine what strategy to follow to enter potentially this market.

INTER-LINKAGES OF THE SERVICES SERVICE INDUSTRIAL

CLUSTERS IN THE PROVINCIAL ECONOMY

As an indicator of the integrated nature of the above-identified sectors, one can determine the backward and forward multipliers of each of the primary services cluster sectors of the NWP. For a particular sector, the backward multiplier shows the connections with upstream industries and the forward multiplier the connections with downstream industries. Put differently, the forward and backward multipliers measure the effect on the output of downstream and upstream sectors respectively resulting from a one-unit increase in a sector's value added (Commission of the European Communities 2007). 
TABLE 4 Categorisation of Sectors According to Their Backward and Forward Inter-Linkages

\begin{tabular}{llll}
\hline Variables & Forward-oriented & & No rel. forw. effects \\
\hline $\begin{array}{l}\text { Backward- } \\
\text { oriented }\end{array}$ & $\begin{array}{l}\text { Key sectors with } \\
\text { widely spread effects }\end{array}$ & $\begin{array}{l}\text { Key sectors with for- } \\
\text { ward effects concen- } \\
\text { trated }\end{array}$ & $\begin{array}{l}\text { Backward-oriented } \\
\text { sectors with widely } \\
\text { spread effects }\end{array}$ \\
\cline { 2 - 4 } & $\begin{array}{l}\text { Key sectors with back- } \\
\text { ward effects concen- }\end{array}$ & $\begin{array}{l}\text { Key sectors without } \\
\text { widely spread effects }\end{array}$ & $\begin{array}{l}\text { Backward-oriented } \\
\text { sectors without widely } \\
\text { spread effects }\end{array}$ \\
& trated & Forward-oriented & $\begin{array}{l}\text { Sectors with weak } \\
\text { inter-linkages with the } \\
\text { No relevant }\end{array}$ \\
$\begin{array}{l}\text { Forward-oriented } \\
\text { backward }\end{array}$ & sectors with widely & $\begin{array}{l}\text { sectors without widely } \\
\text { spread effects }\end{array}$ & rest of the economy \\
\hline
\end{tabular}

notes Adapted from the Commission of the European Communities $(2007,15)$.

This enables us to categorize each primary services clusters' sectors on the strength and nature of their connections with the rest of the provincial economy. A sector is classified as forward-oriented if its forward multiplier value is greater than the average forward multiplier size for all sectors of the economy. Also, a sector is said to be backward-oriented if its backward multiplier value is greater than the average backward size for all sectors of the economy. 'Key sectors' are then classified as those which are simultaneously backward and forward-oriented, reflecting strong connectivity across the entire provincial economy. Also, we can distinguish between sectors that are linked to multiple sectors versus those concentrated in only one or a few sectors (Commission of the European Communities 2007). Table 4 presents such a categorization of the different primary services cluster sectors in the NWP economy.

Figure 5 shows the classification of the activities in the NWP's SAM based on the classification framework of table 4. The figure shows that all four of the primary services cluster sectors (i.e., building and other construction; trade; communication; and real estate) are classified as 'key sector', which is both backward- and forward-oriented. Three other services sectors also fall within the 'key sector' category.

This elementary depiction of the interdependence of the four primary services cluster sectors can be extended by looking at their trade multipliers.

TRADE MULTIPLIERS

The above trade analysis can be extended by the computation of trade multipliers of which the results are shown in table 5. Unfortunately, since 


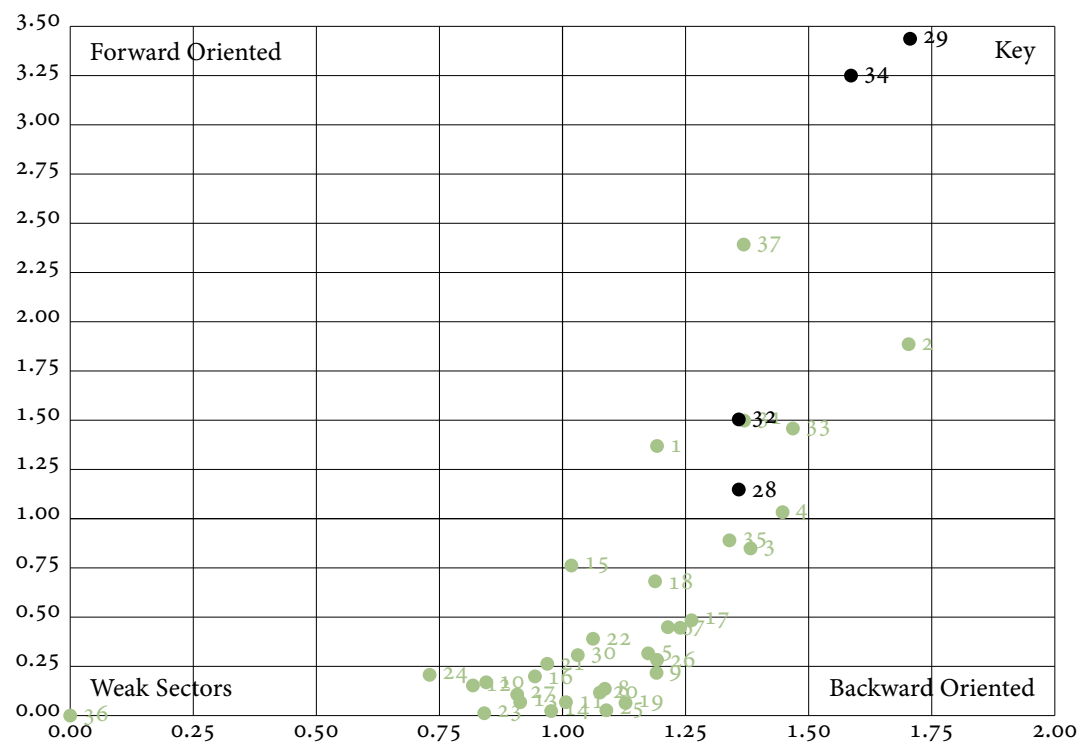

FIGURE 5 Backward and Forward Linkages of the Services Clusters/Sectors (28 - Building and other Construction, 29 - Trade, 32 - Communication, 34 - Real Estate; based on data from Development Bank of Southern Africa, see http://www.dbsa.org)

the 2006 North West provincial SAM has a distinctive rest of the world account (only distributed by destination into rest of South Africa and rest of the world), the value of the import dependence multiplier is close to one for all services accounts. Conversely, the export dependence multiplier shows the change in total income of each domestic rest of the world account resulting from a uniform increase in the flow of income from the rest of the world while keeping fixed the composition of the external account.

The second column in table 5 details own or within-group effects (i.e., total multiplier effect). The wholesale and retail trade and real estate services sectors have the largest multiplier effects, with building and other construction and communication significantly smaller. This indicates that the former would result in greater knock-on effect throughout the provincial economy given an increase in exports.

Apart from this, open-loop multiplier effects (column 4) are, in all cases, quite small. In terms of the open loop effect, the import dependence sub-matrix denotes the direct shares of external expenditure, while the export dependence matrix captures the direct shares of external income. 
TABLE 5 Trade Multipliers for the NWP to the Rest of the World (2006)

\begin{tabular}{|c|c|c|c|c|}
\hline$(1)$ & $(2)$ & (3) & (4) & (5) \\
\hline \multicolumn{5}{|l|}{ Import Dependence Multipliers } \\
\hline Electricity & 0.8854 & 0.1343 & 0.1283 & 0.0578 \\
\hline Water & 0.8828 & 0.2244 & 0.1250 & 0.0574 \\
\hline Building and Other Construction & 0.8332 & 0.3210 & 0.1889 & 0.1036 \\
\hline Trade & 0.7796 & 0.1918 & 0.2640 & 0.1360 \\
\hline Accommodation & 0.8721 & 0.2438 & 0.1386 & 0.0692 \\
\hline Transport & 0.8389 & 0.2284 & 0.1873 & 0.0859 \\
\hline Communication & 0.7467 & 0.3063 & 0.2812 & 0.1305 \\
\hline Insurance & 0.6888 & 0.1329 & 0.3179 & 0.1347 \\
\hline Real Estate & 0.7524 & 0.2890 & 0.2515 & 0.1135 \\
\hline Business Services & 0.7742 & 0.0441 & 0.2172 & 0.0911 \\
\hline Community, Social and Personal Services & 0.7759 & 0.2130 & 0.2788 & 0.1425 \\
\hline \multicolumn{5}{|l|}{ Export Dependence Multipliers } \\
\hline Electricity & 0.0260 & 0.0163 & 0.0037 & 0.0024 \\
\hline Water & 0.0077 & 0.0023 & 0.0026 & 0.0017 \\
\hline Building and Other Construction & 0.0357 & 0.0219 & 0.0063 & 0.0042 \\
\hline Trade & 0.1696 & 0.0747 & 0.0271 & 0.0177 \\
\hline Accommodation & 0.0311 & 0.0033 & 0.0044 & 0.0029 \\
\hline Transport & 0.1056 & 0.0290 & 0.0137 & 0.0087 \\
\hline Communication & 0.0611 & 0.0262 & 0.0130 & 0.0086 \\
\hline Insurance & 0.0645 & 0.0064 & 0.0208 & 0.0142 \\
\hline Real Estate & 0.1311 & 0.0268 & 0.0528 & 0.0350 \\
\hline Business Services & 0.0544 & 0.0276 & 0.0104 & 0.0068 \\
\hline Community, Social and Personal Services & 0.1500 & 0.0760 & 0.0228 & 0.0151 \\
\hline
\end{tabular}

Notes Column headings are as follows: (1) services sectors, (2) total multiplier, (3) transfer effects, (4) open-loop effects, (5) closed-loop effects.

The indirect or closed-loop effects (column 5) in table 5 show that the magnitude of these numbers is also quite small across the four primary services cluster sectors, but much larger when compared to the other services sectors in the provincial economy. When thinking in terms of the Leontief inverse, it can be seen that when leaving out other domestic linkages it leads to an underestimation of the total multiplier income accruing to domestic production activities. This is a universal problem when the 
scope of linkage analysis among domestic institutions is restricted (Tarp, Roland-Holst, and Rand 2002).

Table 5 highlights that the bulk of the benefits arising from policies committed to services growth and innovation, through exports, arise not from the original target sector, but instead as a result of the series of economic connections of which it forms a part. Policymakers fail to see the total costs of their decisions when solely relying on pragmatism and targeting. Policies set on growing and deepening endogenous linkages across the economy, such as market reform policies, will more than likely achieve the most success (Tarp, Roland-Holst, and Rand 2002).

\section{Conclusions and Policy Recommendations}

The first aim of this paper was to propose service industrial cluster formation as an approach to stimulate service innovation in the NW P. Four service industrial clusters were identified for the NWP. These clusters have potential transformative power to enhance service innovation namely (i) communication, (ii) real estate, (iii) building and other construction and (iv) retail and wholesale trade. The results also show that two of the four clusters' services have REOS according to the TRADE-DSM ${ }^{\circ}$ for services. The NWP can formulate very specific export promotion strategies based on these results, for each sector that shows potential in specific countries. It is however very important to take note that even though these results are statistically viable REOS, it is still necessary for the NWP to add further value to these results and add in-market information that could influence the final decisions they make. Some market information is not quantifiable and cannot be put into a model or calculated, for example, specific market conditions in Africa that may affect a firm's actions in that market or specific economic conditions that influence a sector in a short period.

The multipliers show that the wholesale and retail trade, as well as real estate services sectors, would have the largest knock-on benefits in the provincial economy via an increase in their exports. The trade multiplier results show that the majority of benefits arising from a focussed export promotion of services arise not from the original target sector, but from the fabric of economic linkages in which it is embedded. This paper recommends that provincial government use these results to develop specialised services for cluster development in the region. This can initiate or strengthen the competitive advantage of the firms in these sectors and assist in diversifying the output from the province. 
It is recommended that vested interests in industrial cluster formation in the NWP gain an in-depth understanding of the different types of clusters so as to gain an understanding of the characteristics and the necessary conditions required for successful cluster formation (van Dijk and Sverrisson 2003). A distinguishing feature of clusters in developed countries is technology and innovation in product and process designs. This sets clusters in developed countries apart and enables them to become world leaders and standard-setters (Schmitz and Nadvi 1999). Of note to the NWP are high technology clusters. This type of clusters comprises of firms from different, technologically unrelated industries as is the case of the four service clusters identified in this paper (Enright 2003; Amin 1994). This empowers the cluster with innovative capabilities as the technologies of one industry can be adopted to develop new products and new processes in another (Pisa 2014).

The North West provincial government can use these results to formulate clusters by encouraging cooperation between services firms. To drive the success of these clusters, incentives should be offered, and support to build efficient capabilities (Pisa 2014). The NWP government has a crucial part in building sufficient capabilities in these clusters, and assisting them to grow. However, the type of support offered must be carefully designed. Maggioni (2006) suggests that policies should aim to enhance micro-level incentives which provide support to small firms and entrepreneurs to overcome obstacles of commercialisation in the initial phases of development.

Further to this, it is also important to note the needs to services firms specifically, as they are vastly different from firms in other sectors. The NW P government should include knowledge and expertise of specialised services sector experts. Some of the major constraints in the initial phases of development relate to access to finance and big tax constraints that can be overcome by including experts from the private sector that can help design incentives that can actively reduce these obstacles.

In conclusion, services innovation clusters can hold various benefits for economic growth and diversification in the NWP of South Africa. However, this is also an example of how services innovation clusters can contribute to a country's economy as a whole, and these types of policy approaches are crucial to development in all developing countries. Therefore, the method applied in this paper should offer valuable results to any developing countries aiming to diversify and expand their economies away from traditional growth sectors. 


\section{References}

Albaum, G., J. Strandscov, and E. Duerr. 2004. International Marketing and Export Management. Wokingham: Addison-Wesley.

Amin, A. 1994. Post-Fordism: A Reader. Oxford: Blackwell.

Awuah, G. 2009. 'The Impact of Globalisation and Trade Liberalisation on Competitiveness of Firms in Less Developed Countries: A Longitudinal Study'. International Journal of Business Research 9 (3): 7-19.

Barrett, M., E. Davidson, J. Prabhu, and S. Vargo. 2015. 'Service Innovation in the Digital Age: Key Contributions and Future Directions'. Management Information Systems Quarterly 39 (1): 135-54.

Bishop, P., and P. Gripaios. 2007. 'Explaining Spatial Patterns of Industrial Diversity: An Analysis of Sub-Regions in Great Britain'. Urban Studies 44 (9): 1739-57.

Chesbrough, H. 2011. Open Services Innovation: Rethinking Your Business to Grow and Compete in a New Era. San Francisco: Jossey-Bass.

Commission of the European Communities. 2007. 'Implementing the New Methodology for Product Market and Sector Monitoring: Results of a First Sector Screening. SEC(2007) 1517, Commission of the European Communities, Brussels.

Credit Guarantee. 2010. 'Credit Notes No. 119'. http://www.creditguarantee .co.za/downloads/credit\%2onotes/2010_Credit_Notes_March.pdf.

Cuyvers, L., and W. Viviers, eds. 2012. Export Promotion: A Decision Support Model Approach. Johannesburg: Sun Press.

Czinkota, M. R. 2002. 'Export Promotion: A Framework for Finding Opportunity in Change'. Thunderbird International Business Review 44 (3): 315-25.

Czinkota, M. R., and I. A. Ronkainen. 2007. International Marketing. 8th ed. Mason, он: Thomson South-Western.

Dietzenbacher, E. 1992. 'The Measurement of Inter-Industry Linkages: Key Sectors in the Netherlands'. Economic Modelling 9 (4): 419-37.

Doole, I., and R. Lowe. 2004. International Marketing Strategy: Analysis, Development and Implementation. London: Thomson Learning.

Economic and Social Commission for Asia and the Pacific. 2009. Trade Statistics in Policymaking: A Handbook of Commonly Used Trade Indices and Indicators. Revised Edition. New York: United Nations.

Eitzen, H. C. 2012. 'Dilemmas of Diversification: Regional Economic Development and Business-Service Industrial Clusters in China and Kazakhstan.' Journal of Emerging Knowledge on Emerging Markets 4 (1-2): 2-26.

Enright, M. J. 2003. 'Regional Clusters: What We Know and What We Should Know' In Innovation Clusters and Interregional Competition, 
edited by J. Bröcker, D. Dohse, and R. Soltwedel, 99-129. Berlin: Springer.

European Commission. 2012. The Smart Guide to Service Innovation. Brussels: European Commission.

Feldman, M., J. Francis, and J. Bercovitz. 2005. 'Creating a Cluster While Building a Firm: Entrepreneurs and the Formation of Service Industrial Clusters. Regional Studies 39 (1): 129-41.

Grater, S., and W. Viviers. 2012. 'Adaptation and Application of the DSM for Services in South Africa'. In Export Promotion: a Decision Support Model Approach, edited by L. Cuyvers and W. Viviers, 205-28. Johannesburg: Sun Press.

Grater, S., E. Steenkamp, W. Viviers, and L. Cuyvers. 2014. 'Combining Export Promotion of Products and Services: The Case of South Africa' Southern African Business Review 18 (3): 93-118.

Hansen, M. T., and J. Birkinshaw. 2007. 'The Innovation Value Chain'. Harvard Business Review 85 (6): 121-30.

Hoekman, B. 1996. 'Assessing the General Agreement on Trade in Services'. In The Uruguay Round and the Developing Countries, edited by W. Martin and L. A. Winters, 88-124. Cambridge: Cambridge University Press.

Kingstone, P. 2012. 'Brazil's Reliance on Commodity Exports Threatens its Medium- and Long-Term Growth Prospects'. Americas Quarterly, Summer. http://www.americasquarterly.org/kingstone

Lall, S. 1992. 'Technological Capabilities and Industrialisation'. World Development 20:165-86.

Leonidou, L. C., C. Katsikeas, D. Palihawadana, and S. Spyropoulou. 2007. 'An Analytical Review of the Factors Stimulating Smaller Firms to Export: Implications for Policy-Makers'. International Marketing Review 24 (6): 735-70.

Lusch, R. F., and S. Nambisan. 2015. 'Service Innovation: A Service-Dominant Logic Perspective'. Management Information Systems Quarterly 39 (1): 155-75.

Maggioni, M. A. 2006. 'Mors Tua, Vita Mea? The Rise and Fall of Innovative Service Industrial Clusters.' In Cluster Genesis: The Origins and Emergence of Technology, edited by P. Braunerhjelm and M. Feldman, 219-42. Oxford: Oxford University Press.

Nordås, H. K., and Y. Kim. 2013. 'The Role of Services for Competitiveness in Manufacturing. oeCD Trade Policy Papers 148, oECD, Paris.

Parra, J. C., and Q. Wodon. 2009. 'Simsip_sa M: A Tool for the Analysis of Input - Output Tables and Social Accounting Matrices.' Mimeo, World Bank, Washington, DC.

Pisa, N. 2014. 'Identifying Industrial Clusters for Competitiveness: Policy Implications for Economic Development in the North West Province 
of South Africa.' Doctoral thesis, North West University, Potchefstroom.

Porter, M. E. 1989. The Competitive Advantage of Nations. New York: The Free Press.

- On Competition. Cambridge, m A: Harvard Business School Press.

- 2000. 'Location, Competition and Economic Development: Local Clusters in a Global Economy'. Economic Development Quarterly 14 (1): 15-34.

Prologis. 2015. 'The Evolution of Logistics Real Estate Clusters.' https:// www.prologis.com/sites/corporate/files/documents/2017/02/ LogisticsClustersWhitePaper_August2015.pdf

Schmitz, H., and K. Nadvi. 1999. 'Clustering and Industrialisation: Introduction'. World Development 27 (9): 1503-14.

Sheff, Y. 2012. 'Driving Growth and Employment through Logistics.' MIT Sloan Management Review 54 (1): 20-2.

Smillie, I. 1991. Mastering the Machine. London: Intermediate Technology Publications.

Tallman, S., M. Jenkins, N. Henry, and S. Pinch. 2004. 'Knowledge, Clusters, and Competitive Advantage'. Academy of Management Review 29 (2): 258-71.

Tarp, F., D. Roland-Holst, and J. Rand. 2002. 'Trade and Income Growth in Vietnam: Estimates from a New Social Accounting Matrix'. Economic Systems Research 14 (2): 157-84.

United Nations. 2002. Manual on Statistics of International Trade of Services. New York: United Nations.

Van Dijk, M. P., and A. Sverrisson. 2003. 'Enterprise Clusters in Developing Countries: Mechanisms of Transition and Stagnation.' Entrepreneurship and Regional Development 15:183-206.

Van Laere, K., and A. Heene. 2003. 'Social Networks As a Source of Competitive Advantage for the Firm.' Journal of Workplace Learning 15 (6): 248-58.

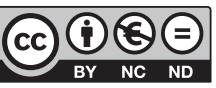

This paper is published under the terms of the Attribution-

NonCommercial-NoDerivatives 4.o International (CC B Y-NC-ND 4.0)

License (http://creativecommons.org/licenses/by-nc-nd/4.o/). 